Pamiętnik Literacki 2020, 1, s. 33-50

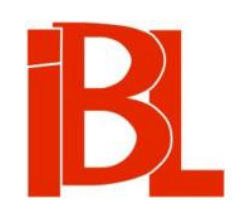

\title{
Poezja religijna masonów polskich epoki oświecenia - rekonesans
}

\author{
Tomasz Chachulski
}




\section{POEZJA RELIGIJNA MASONÓW POLSKICH EPOKI OŚWIECENIA - REKONESANS}

Tajemnicza „sztuka królewska” budziła różne emocje od chwili swojego powstania i w większym czy mniejszym stopniu zaprzątała uwagę publiczną w XVIII i na początku XIX wieku. Klemens XII wydał 24 IV 1738 bullę In eminenti apostolatus specula, jednoznacznie zabraniajacca jej uprawiania, zakaz potwierdził Benedykt XIV bullą Providas romanorum pontificum z 18 III 1751. Nie uczynił tego wszakże Klemens XIV ${ }^{1}$, co stało się źródłem wielu spekulacji. W kraju, którego znakomity odsetek społeczeństwa szlacheckiego tworzyli rzymscy katolicy, a w niższych warstwach także przedstawiciele kościołów reformowanych oraz kościołów wschodnich i wyznawcy judaizmu, sztuka ta w zasadzie powinna się znaleźć poza sferą zainteresowań. Póki była „zabawa” dworskich środowisk polskiej arystokracji - w Warszawie, Wiśniowcu na Podolu, Poznaniu, Dukli, ale także przedmiotem fascynacji środowisk mieszczańskich w Gdańsku - nie stanowiła problemu i poza sporadycznymi przypadkami nie budziła emocji ${ }^{2}$. Sytuacja zmieniała się wraz z upływem kolejnych dziesięcioleci, rozwojem i wewnętrznymi przekształceniami nurtów oświeceniowych, przeobrażeniami politycznymi związanymi z pierwszym rozbiorem Rzeczypospolitej, pojawieniem się przedstawicieli innych narodowości (szczególnie wojskowych i urzędników) na terenach austriackiej Galicji i na obszarach zagarniętych przez Prusy ${ }^{3}$. W latach osiemdziesiątych XVIII wieku sieć lożowa Rzeczypospolitej była już stosunkowo gęsta, jej reprezentanci zaś odgrywali coraz większą rolę - dość przypomnieć ich znaczącą obecność i zaangażowanie w sprawy publiczne na Sejmie Czteroletnim. W następnych dziesięcioleciach liczba masonów rosła, a biorąc pod uwagę także lata 1815-1821 (tj. od czasu politycznej stabilizacji po Kongresie Wiedeńskim do chwili wprowadzenia w życie kolejnych zakazów działal-

1 Zob. L. Ha s s, Wolnomularstwo $w$ Europie Środkowo-Wschodniej $w$ XVIII $i$ XIX wieku. Wrocław 1982, s. 68, 77. Zob. też Documenta Catholica Omnia. Omnium Paparum, Conciliorum, SS Patrum, Doctorum Scriptorumque Ecclesiae qui ab Aevo Apostolico ad usque Benedicti XVI Tempora Floruerunt. Na stronie: http://www.documentacatholicaomnia.eu (data dostępu: 28 IX 2019).

Zob. ibidem, s. 69 n.

Wszystkie te procesy szeroko opisuje Has s w przywoływanej tu monografii, zwłaszcza w rozdziałach: Pierwsze kroki $w$ Europie Środkowo-Wschodniej. Od lat dwudziestych do połowy sześćdziesiątych XVIII w., W dziesięcioleciach oświecenia. Lata sześćdziesiąte i siedemdziesiąte i W zenicie oświecenia. Dni wielkości $i$ schytku lóż $w$ latach osiemdziesiatych. Wstęp do publikowanego tu artykułu bardzo wiele zawdzięcza ustaleniom autora. 
ności wolnomularskiej), uczeni piszą o wstępowaniu przedstawicieli artystycznych elit do lóż jako o zjawisku nieomal „powszechnym”4. Ostrożniej podchodził do tej kwestii Stanisław Załęski, pracujący w dużej mierze na tych samych materiałach historycznych, co wielu badaczy schyłku XX wieku, choć o 100 lat wcześniej:

Z tym wszystkim masonia w Polsce nie była nigdy popularna, przyjęła się tylko w wyższych warstwach [...], zrazu jako moda, potem jako instytucja humanitarna, wreszcie jako agitacja polityczna. Prawda, że należały do niej najwybitniejsze osobistości na polu polityki, wojskowości i nauki [... $]^{5}$.

Wśród braci, w ślad za członkami wielkich rodów magnackich czy arystokratycznych, jeszcze w XVIII wieku znaleźli się najbardziej znani pisarze polskiego oświecenia: Julian Ursyn Niemcewicz, Franciszek Dionizy Kniaźnin, Wojciech Bogusławski; a także inni artyści: malarze, muzycy - Marcello Bacciarelli, Zygmunt Vogel, Wincenty Lessel - choć trzeba pamiętać, iż na skutek skomplikowanego systemu powiązań, relacji mecenasowskich, zmian o charakterze politycznym i dramatycznych wydarzeń historycznych pojawianie się i znikanie poszczególnych osób z rejestrów wolnomularskich musiało być na porządku dziennym, zwłaszcza że samo życie lóż masońskich zależało od aktywności jej członków oraz od relacji z lożami wyższego stopnia, które je powoływały. Wystarczyło zatem nieporozumienie formalne albo zawirowanie polityczne, by sparaliżować działania lub odwrócić uwagę braci od funkcjonowania loży i w efekcie doprowadzić do jej zamarcia.

W ostatnich latach istnienia Rzeczypospolitej i po jej upadku rangę straciły loże ulokowane w magnackich siedzibach na prowincji. W krótkim czasie po wkroczeniu wojsk pruskich do dawnej stolicy, w wyniku napływu niemieckich urzędników, „sekta farmazonii warszawskiej” stała się jednym z najsilniejszych źródeł oddziaływania na polskie środowiska ${ }^{6}$. Zasadniczą rolę zaczęli odgrywać stosunkowo młodzi oficerowie i urzędnicy, redaktorzy i autorzy utworów scenicznych, poeci i krytycy teatralni, pełniący zresztą nierzadko kilka $z$ tych funkcji kolejno lub równocześnie.

Przedmiotem uwagi nie jest wszakże ani ruch wolnomularski jako taki, ani „religijny” wymiar jego działalności, ale tylko jeden z jego literackich przejawów pieśni zawierające w sobie tematy, wątki i motywy związane $z$ transcendentnym postrzeganiem rzeczywistości, wyrażającym się $\mathrm{w}$ bezpośrednich zwrotach do Stwórcy, w prośbach, modlitwach, hymnach, pochwałach, w wykorzystaniu wątków i tematów biblijnych: staro- i nowotestamentowych, pieśni wyrastających z tradycji katolickich, a nawet w sakralizacji niektórych pojęć i idei (Cnota - Feliks Gawdzicki; Przyjaźń, Ojczyzna - Tadeusz Wolański, za Ignacym Krasickim; Miłość bliźniego 〈w wierszu Pieśń o przyjaźni i miłości bliźniego〉, a w jednej z anonimowych Pieśni ogólnych - „Majestat, Kościół, Ojczyzna”, P 5977). Pisano już:

4 E. Wichrowska, Polska poezja wolnomularska $w$ XVIII $i$ na początku XIX wieku. „Ars Regia” 1992, nr 1, s. 65.

$5 \quad$ S. Z Z ł łę s ki, O masonii w Polsce od roku 1738 do 1822. Na źródłach wyłacznie masońskich. Cz. 1. Wyd. 2, popr., w dwóch częściach. Kraków 1908. Reprint: Warszawa 2004, s. 261.

$6 \quad$ L. H a s s, Sekta farmazonii warszawskiej. Pierwsze stulecie wolnomularstwa w Warszawie (17211821). Warszawa 1980.

7 Skrótem tym odsyłam do: T. W olański, Pieśnik wolnomularski, na użytek wspaniałego Wielkiego Wschodu Narodowego i pracujacych pod jego konstytucyja $w$ Królestwie Polskim loż regular- 
badacze ruchu wolnomularskiego powinni traktować teksty literackie (poetyckie) jako wiarygodne zaplecze źródłowe, w którym zawarty został podstawowy system światopoglądowy masonerii w jej idealistycznym, wzorcowym wymiarze ${ }^{8}$.

Tu jednak, na ile jest to możliwe, skupimy się wyłącznie na obserwacji samych utworów literackich czy paraliterackich ${ }^{9}$.

Określenie „poezja religijna” ma w tym przypadku charakter w pewnej mierze umowny przede wszystkim dlatego, że w samym ruchu wolnomularskim, poza wymogiem doskonałości moralnej jego członków, przekonaniem o transcendentnym porządku świata i aktywnym zwrocie do Stwórcy, brakuje daleko idących elementów systemowych, tj. stałych praktyk wyznaczających relację między społecznością braci (i sióstr) a sferą sacrum ${ }^{10}$. Istnieją, jak się wydaje, przynajmniej dwa powody, dla których tak się działo: po pierwsze, obowiązująca zasada uniwersalizacji ruchu, w założeniu łączącego przedstawicieli różnych wyznań chrześcijańskich, a nawet rozmaitych religii ( $\mathrm{z}$ czasem także judaizmu), prowadzaca do ugruntowania świadomości braci na „zlaicyzowanej moralności chrześcijańskiej” i (przynajmniej na pozór) „bezreligijnym humanitaryzmie”"11; po drugie, ze względu na fakt głębokiego przepojenia całości praktyk lożowych odczuciem transcendentnego porządku rzeczywistości, odzwierciedlającego się w często powtarzanych zwrotach do Wielkiego Architekta, Budownika Świata - gwaranta realizacji przyszłego „królestwa niebieskiego" na ziemi ${ }^{12}$, ale nie mającego w strukturze obrzędów wolnomularskich szczególnie wyeksponowanego i trwale określonego miejsca:

\author{
W którejkolwiek żyjem wierze, \\ Stanie, losie lub narodzie, \\ Kochajmy się wszyscy szczerze, \\ Wszyscy w świętej żyjmy zgodzie. \\ A ten związek, co nas lepi, \\ Niech moc cnoty w sercach krzepi! \\ Ileż wieków świat już liczy \\ Co zdziwiły sławą Ziemię,
}

nych. T. 1. Wrocław 5818 [1818]. Na stronie: https://polona.pl/item/piesnik-wolno-mularski-nauzytek-wspanialego-wielkiego-wschodu-narodowego-i-pracujacych,Njg1ODgyMjc/12/\#info:meta data (data dostępu: 28 IX 2019). Ponadto stosuję skrót A = E. Z. W i c h r ow s k a, Antologia poezji masońskiej. Warszawa 1995. Liczby po skrótach wskazują stronice. Cytaty zmodernizowano według obowiązujących zasad interpunkcyjnych i ortograficznych.

8 J. Głażew s ki, Wieczysty węzeł ludzkości. Pieśni łańcuchowe jako gatunek rytualnej poezji masońskiej. „Napis. Pismo poświęcone literaturze okolicznościowej i użytkowej” seria 16 (2010), s. 412.

9 Wszechstronnie nakreśliła sytuację ideową, w jakiej rozwijała się XVIII-wieczna poezja religijna, T. Ko s t ki e w i c z ow a (Poezja religijna czasów oświecenia w Polsce. W zb.: Polska liryka religijna. Red. S. Sawi cki, P. N ow a czyń s ki. Lublin 1983, s. 111-114; Literatura wobec wiary. W: Polski wiek światet. Obszary swoistości. Wrocław 2002, s. 344-351).

10 Zob. popularne ujęcie na stronie: https://pl.wikipedia.org , wiki , Religia (data dostępu: 28 VIII 2019). O obecności kobiet w lożach pisze się ostatnio coraz częściej, zob. P. Fiuk, Wizerunki „sióstr swobody” w wolnomularskiej literaturze polskiego oświecenia. W zb.: Wiek XVIII (nie tylko) w szkole. Literatura - historia - kultura - sztuka. Red. B. Mazurkowa, z udziałem M. Marc in kows ki j. Katowice 2013.

11 Has s, Wolnomularstwo $w$ Europie Środkowo-Wschodniej $w$ XVIII $i$ XIX wieku, s. 146.

12 Zob. J. Starobinski, Światła i władza. Watki masońskie w „Czarodziejskim flecie”. Przeł. M. Tarnowska. „Znak” 1992, nr 451, s. 85 n. 


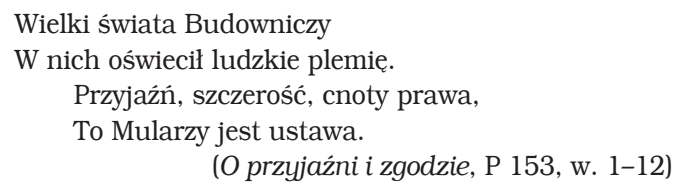

Ludwik Hass pisał: „Duch tolerancji i wyrozumiałości wyrażał się m.in. w tym, że w obrzędowości zachowano wszystko, co przypominało pewne pojęcia i idee religijne $[. .] "$.13 . Nie polemizując $z$ jednym $z$ najwybitniejszych znawców problematyki wolnomularskiej w Polsce ostatniego stulecia, warto tylko zauważyć, że wolnomularska obrzędowość wykorzystywała po prostu wrośnięte w zachowania europejskich społeczności sposoby uwznioślania właściwych ludziom pragnień, sakralizacji kategorii moralnych, wreszcie naturalnego dla człowieka poszukiwania dróg do wskazywanego już tu wcześniej transcendentnego porządku rzeczywistości. Fakt zaś początkowego zachowania „pojęć i idei religijnych”, po upadku rewolucji francuskiej i wojnach napoleońskich, przynajmniej w Polsce doprowadził do wyraźnego pogłębienia i rozwinięcia tych pojęć i idei na początku XIX wieku, a nie do ich zredukowania. Paradoksalnie można by powiedzieć, że oświeceniowa $\mathrm{z}$ ducha „wiara w wartość człowieczeństwa” ${ }^{14}$, która wyrażała się w tym przypadku w ruchu wolnych mularzy, na polskim gruncie i w warunkach wielkich przemian politycznych i społecznych schyłku XVIII i początku XIX wieku doprowadziła do odnowienia pragnień związanych $z$ sakralnymi uzasadnieniami dla ludzkich poczynań.

$Z$ drugiej jednak strony, dla członków Kościoła rzymskokatolickiego wstapienie do loży łączyło się z naruszeniem zasad przyjętej doktryny, tj. ze złamaniem zakazu sformułowanego w papieskiej bulli wobec niesformalizowanego jeszcze wówczas, ale powszechnie przyjętego charyzmatu nieomylności papieża w sprawach wiary ${ }^{15}$. Co prawda, w toku wielkich przemian oświeceniowych, rewolucji francuskiej, w Polsce - rozbiorów, a potem wojen napoleońskich, losów papiestwa w dobie działalności cesarza Francuzów i konsekwencji związanych ze wszystkimi tymi procesami i działaniami: zatem $\mathrm{z}$ rozpadem wielu nie kwestionowanych wcześniej przekonań i pewników, chyba nie wszyscy z braci i nie w pełni byli tego świadomi; do tego zagadnienia wrócimy jeszcze w dalszej części artykułu.

Definicja wyrastająca $z$ tradycji rzymskokatolickich w większym stopniu zwraca uwagę na fakt, że:

Religia [...] [jest to] realna, dynamiczna i osobowa relacja między człowiekiem a rzeczywistością transcendentną [...], wyrażająca się w uznaniu przez człowieka jej nadrzędności jako źródła istnienia i ostatecznego celu dążeń, zróżnicowana historycznie, kulturowo, społecznie, instytucjonalnie i psychologicznie; na jej strukturę składają się: prawdy wiary (doktryna), zasady życia moralnego, kult i organizacja; głównym przedmiotem religii jest Bóg, na różne sposoby objawiający prawdy religijne ukazujące Jego naturę i działanie (Stwórca i Zbawiciel) ${ }^{16}$.

H a s, Wolnomularstwo $w$ Europie Środkowo-Wschodniej $w$ XVIII i XIX wieku, s. 91.

P. Li s i c ki, Mroczne dziedzictwo oświecenia. „Znak” 1992, nr 451, s. 31.

Breviarium fidei. Wybór doktrynalnych wypowiedzi Kościoła. Red. I. B o kw a. Oprac. I. B o kw a [i in.]. Wyd. 3. Poznań 2007, s. 259, 265-271.

Religia. Hasło w: Encyklopedia katolicka. Red. E. Gi gilewi cz. T. 16. Lublin 2012, kol. 1394. Skróty w cytowanym haśle rozwijam bez zaznaczenia. 
Zatem - zamykając ten wątek - poezja religijna będzie tu przejawem pewnego nastawienia uczestników spotkań lożowych, pragnienia ugruntowania wyższej sankcji i poczucia przynależności do sakralnego porządku świata, nie zaś do określonego wyznania, a nawet religii. W praktyce jednak spoza wolnomularskich formuł raz za razem ujawniać się będą tradycyjne sposoby wyrażania i językowe przyzwyczajenia, odzwierciedlające wpisanie konkretnych członków loży w rzeczywistość wyznaniową, bez względu na wyrazistość deklaracji braci z tych oraz innych miejsc i środowisk.

$\mathrm{Z}$ oczywistych powodów próba nawet wstępnego przedstawienia twórczości literackiej o wskazanym tu charakterze, przekładów z języka niemieckiego bądź francuskiego, jak również procesu wykorzystywania pieśni czerpanych spoza środowiska wolnomularskiego, powinna zostać uporządkowana pod względem chronologicznym, pozwalającym dostrzec dynamikę przemian tego rodzaju pisarstwa ${ }^{17}$. Niestety, dostępne dziś w unikatowych egzemplarzach polskie śpiewniki masońskie zestawiono i opublikowano przede wszystkim na początku XIX wieku, najczęściej w drugiej jego dekadzie. Sumują one wcześniejsze dokonania, utrudniajac wszakże obserwację historycznego rozwoju tego ciekawego zjawiska ${ }^{18}$.

Należy też dodać, że przedmiotem uwagi są jedynie te utwory o przedstawianych już cechach, które w jakikolwiek sposób zostały poświadczone jako śpiewane w lożach lub zapisane bądź drukowane na potrzeby posiedzeń lożowych. Nie uwzględniono wierszy autorstwa znanych członków ruchu wolnych mularzy, ale opublikowanych oficjalnie poza tym środowiskiem - dotyczy to szczególnie takich pisarzy, jak Kazimierz Brodziński (Hymn do Boga, Do Boga ${ }^{19}$ ), Kajetan Koźmian, Ludwik Osiński (Wiersz o Dobroczynności), Bruno Kiciński, a także wypowiedzi autorów realizujących gatunki różne od lirycznych, np. opera oraz inne dzieła teatralne bądź dramatyczne czy nawet fragmenty prozatorskie (choćby w twórczości Cypriana Godebskiego).

Mimo że propozycje pieśni masońskich i wskazanie wagi śpiewu zbiorowego podczas uroczystości i zwykłych praktyk lożowych znalazły się już w konstytucji Jamesa Andersona z 1723 roku, polskie pieśni masońskie w większej i bardziej reprezentatywnej liczbie, jak już tu wspomniano, znamy dopiero ze zbiorków wydanych na początku XIX wieku: Józefa Elsnera $(1811)^{20}$, zbiorów przygotowanych

Zob. Głażewski, op. cit., s. 412-413.

Zob. Wichrowska: Polska poezja wolnomularska $w$ XVIII i na poczatku XIX wieku, s. 54; A 207-208. Podobne problemy napotykali także inni autorzy piszący w ostatnich latach o poezji masońskiej, zob. m.in. J. Głażew ski: „Gdzie człek $w$ człeku widzi brata”. Idea braterstwa w okolicznościowej poezji masońskiej. „Wschodni Rocznik Humanistyczny” t. 5 (2008); Wieczysty węzeł ludzkości. Dawniej było podobnie, zob. S. M ał a c h ow s k i - Łe m pi c ki, Wolnomularskie utwory Brodzińskiego. „Pamiętnik Literacki” 1932, z. 1/4.

Oba wiersze powstały w czasach przynależności K. Brodzińskiego do loży, a nawet - ścisłej współpracy z J. Elsnerem przy przygotowywaniu Mszy polskiej do śpiewania z organami na jeden lub dwa głosy kobiece lub męskie - z inicjatywy arcybiskupa Sz. Hołowczyca. Zob. K. B r o dziń s ki, Poezje. T. 1. Oprac., wstęp Cz. Zg orzels ki. Wrocław 1959, s. 211-213, 550-551. Dzieła. Red. S. Pigoń.

[J. Els ner], Pieśni wolnomularskie. [Warszawa 1811]. Na stronie: https://www.dbc.wroc.pl/ dlibra/publication/5534/edition/5298/content (data dostępu: 28 VIII 2019). Stanowią one jedną całość ze zbiorem wydanym niemal równolegle: J. Els n e r, Muzyka do pieśni wolnomularskich. [Warszawa 1811]. Na stronie: https://polona.pl/item/muzyka-do-piesni-wolno-mularskich,MjI2 
przez Feliksa Gawdzickiego (1814) ${ }^{21}$, Tadeusza Wolańskiego (1817 i 1818), Franciszka Budziszewskiego (ok. 1820) ${ }^{22}$ - a pewnie i innych ${ }^{23}$.

Ówczesne wolnomularstwo było nieodrodnym dzieckiem oświecenia i tak jak ono było głęboko zróżnicowane w zależności od lokalnych tradycji, miejsca w Europie, w którym się rozwijało, mentalności braci, osadzenia w sposobie myślenia społeczności protestanckiej (anglikańskiej, luterańskiej), rzymskokatolickiej albo prawosławnej - również $\mathrm{z}$ echami zadawnionych sporów na tle wyznaniowym. $Z$ oczywistych powodów korzystało też nie tylko z języka „lożowego”, terminów, formuł, motywów i symboliki własnej bądź zapożyczonej m.in. od różokrzyżowców, mniej lub bardziej hermetycznej, ale także $z$ bogatego repertuaru słownictwa charakterystycznego dla poezji XVIII-wiecznej. Odnajdujemy więc motywy klasycystycznego podziwu dla odwiecznego porządku świata i jego Stwórcy, rokokowej zabawy, choćby ogrodowej, w której każdy liść i kwiat, układ roślin, ścieżek, fontann i małej architektury nabierały symbolicznego znaczenia, wreszcie sentymentalny program moralnego doskonalenia się człowieka, jego związku z całą czującą naturą, i głęboką troską o biednych, nieszczęśliwych, odrzuconych i wymagających pomocy. Niebagatelna pozostawała też widoczna łączność formuł wolnomularskich $z$ koncepcjami deistycznymi, tak mocno i wyraźnie oprotestowanymi na gruncie katolicyzmu, a zarazem tak głęboko przenikającymi ówczesna poezję religijną, pod pewnymi względami nawet tę, która miała w założeniach absolutnie ortodoksyjny charakter. I wreszcie na koniec trzeba zwrócić uwagę, że ruch masoński przechodził różne fazy inspiracji, zmian poglądów swoich członków, pojawiania się wpływów angielskich, francuskich czy niemieckich i jednoznaczne zdefiniowanie zespołu głównych motywów, jakie spotkamy w utworach literackich jego reprezentantów, jest możliwe tylko przy pewnej dozie tolerancji dla ewentualnych odstępstw od przedstawionych wzorów.

Program społeczno-moralny warszawskiego wolnomularstwa najwięcej zawdzięczał tradycjom sentymentalnym, idei pomocy biednym i zagubionym, wsparcia w nieszczęściu, trosce o potrzebujących pomocy, a tych - w latach wojny polsko-rosyjskiej 1792 roku, powstania kościuszkowskiego, trzeciego rozbioru, wojen napoleońskich i całego ciagu wydarzeń zakończonych Kongresem Wiedeńskim, przywracającym w Europie pozory starego ładu - naprawdę nie brakowało. Znane hasło Franciszka Karpińskiego: „Człowieka nieszczęśliwego ja mam u siebie za rzecz święta”, zapisane w liście do najbliższego $z$ jego pijarskich przyjacióo ${ }^{24}$, doskonale

MTI2MDg/4/\#info:metadata (data dostępu: 28 VIII 2019). O wzajemnych zależnościach obu publikacji zob. T. C h a chuls k i, Pieśni Józefa Elsnera-utwory literackie. W: J. Els n e r, Pieśni / Songs. Wyd. M. Sieradz. / Ed. M. Sieradz. Ed. tekstów pieśni T. Chachulski. / Ed. of texts of songs by T. Chachulski. Warszawa 2018, s. 50-52.

21 F. Gaw dzicki, Pieśni wolnomularskie. B. m., 1814. Na stronie: https://polona.pl/item/piesniwolno-mularskie,OTgwNzQ0Njk/8/\#info:metadata (data dostępu: 28 VIII 2019).

22 [F. B u dzi is ze w s ki, Dziewiętnaście pieśni wolnomularskich. Płock, ok. 1820]. Na stronie: https:// polona.pl/item/19-piesni-wolnomularskich,ODIwNzU4Mzg/4/\#info:metadata (data dostępu: 28 VIII 2019).

23 Zob. Załę ski, op. cit., s. 258.

24 F. Karpińs ki, list do M. Stadnickiego, z 22 III 1788. W: Korespondencja [...] z lat 1763-1825. Zebrał, do druku przygot. T. Mikulski. Komentarz oprac. R. S obol. Wrocław 1958, s. 34. 
oddawało społeczny rys programu wolnomularzy (choć sam Karpiński masonem nie był), szczególnie w dwóch pierwszych dziesięcioleciach XIX wieku. Jeśli ten wizerunek uzupełnimy o solidarność członków loży - przypomnijmy, że bardzo wielu ówczesnych braci to ludzie wykształceni i młodzi, a omawiana poezja miała dość często charakter postulatywny, „Związany z utopijnymi fundamentami ruchu, zmierzającego do urzeczywistnienia projektu "nowego człowieka" [...]"25 - atrakcyjność przekazu musiała być znacząca.

Jak w każdym zamkniętym kręgu, wzajemne relacje budowano na podstawie wypróbowanych już wielokrotnie sposobów. Śpiew stawał się jednym $z$ istotniejszych elementów programu wszystkich posiedzeń loży. Niemała część pieśni narodziła się $\mathrm{w}$ kręgu niemieckim i była po prostu tłumaczona lub spiewana $\mathrm{w}$ oryginale z uwagi na dominację, a później wysoki odsetek braci niemieckiego pochodzenia w warszawskich lożach, szczególnie na początku XIX wieku. Nie bez znaczenia pozostawała także obecność wielu ludzi pióra w kręgach wolnomularskich. Wskazywano już tutaj, że do lóż należeli najwybitniejsi i najbardziej znani poeci pierwszych dwóch dziesięcioleci XIX wieku, autorzy dzieł dramatycznych, twórcy oper, kompozytorzy, ludzie teatru, krytycy literaccy i teatralni.

W ważnej Antologii poezji masońskiej Elżbiety Wichrowskiej - pierwszym tak obszernym polskim wyborze poezji masońskich dostępnym publicznie - motywy religijne pojawiające się w zamieszczonych tam pieśniach zostały zebrane w części zatytułowanej Każdy Mason powinien być chrześcijaninem. Że tak właśnie być musi, zaświadcza fragment Statutu Wielkiej Loży „Cnotliwy Sarmata” z 1769 roku (A 155), wyłączający z grona braci zarówno osoby głęboko zdemoralizowane oraz ateistów, jak i ostentacyjnie, fałszywie („obłudnie”) dewocyjne, a wyznaczający wspólną drogę do doskonałości poprzez udział w praktykach dowolnego spośród wyznań chrześcijańskich (każdy wolnomularz „powinien być chrześcijaninem jakiegokolwiek bądź wyznania” 〈A 155〉). Niewielki to dział, liczący zaledwie cztery utwory o dość podobnym charakterze: niepodpisany Hymn (inc. „O Ty, co ziemi kołyszesz osi”, A 157), z niemieckiego przełożona przez Tadeusza Wolańskiego Modlitwa (inc. „Nieśmiertelnych Naczelniku!”, A 159), kolejny niepodpisany Hymn (inc. „Ty, coś rzeczy stawił w szyku", A 160) autorstwa Jana Drozdowskiego i znów anonimowy Hymn do Boga (inc. „Nasz Budowniku, Tobie cześć i chwała”, A 162).

Zacytujmy kilka najbardziej charakterystycznych fragmentów jednej z tych pieśni, określających kierunek myślenia Wolnych Mularzy.

\footnotetext{
Ku czystej chwale Boskiej Istoty

Wolni Mularze na ziemi łonie

Budują Kościół Światła i Cnoty,

Przemoc go wieków żadna nie schłonie.

Od wszystkich świata okręgów strony

Kościół ten święty będzie uczczony.

$[\ldots \ldots \ldots \ldots \ldots$

W Twoim obliczu, w tej tu świątyni,

Sprawco natury, przed Twym obrazem
} 
Ród Ci Mularzów ofiarę czyni,

Wszyscy Twą wielkość wielbimy razem.

Te serca, co się wiernie jednocza,

$Z$ drogi praw Twoich nigdy nie zbocza.

(Hymn, A 157-158, w. 13-18, 25-30)

Pomijam fragmenty o wydźwięku negatywnym, niedwuznacznie wskazujące na oskarżenia kierowane wobec działań prowadzących do ludzkiego nieszczęścia, niesprawiedliwości i krzywdy, z mniej lub bardziej oddalonej przeszłości. Charakterystyczne dla idei oświecenia krytyka wielkich instytucji i wszelkich form władzy nie uwzględniającej interesów i - jakbyśmy dzisiaj powiedzieli - praw jednostki, sprzeciw wobec „zabobonu” i „ciemnoty” jako źródła zła, pozwalały równocześnie na wyznaczanie pozytywnego programu, który łączył idee oświecenia i wspólnoty, solidarności środowiskowej braci i samodoskonalenia moralnego $z$ jednej strony, z drugiej - szacunku, podziwu, a nawet uwielbienia dla odwiecznego porządku świata i jego Stwórcy. Hymn Drozdowskiego (inc. „Ty, coś rzeczy stawił w szyku”) w większym stopniu akcentuje właśnie ów program pozytywny, w sumie zaś marginalna konstatacja o minionej niezgodzie i braku oświecenia pozwala wskazać przede wszystkim perspektywę wspólnego szczęścia ludzkości połączonej węzłem braterstwa i świadomością wynikającą z upowszechnienia światła mądrości. Ostatni z zamieszczonych tu wierszy, czyli Hymn do Boga (inc. „Nasz Budowniku, Tobie cześć i chwała”), uzupełnia ten zestaw propozycji pozytywnych o powszechną miłość, braterstwo i racjonalne uzasadnienie dla podejmowanych decyzji.

Ale zarówno w utworach zgromadzonych we wspomnianej antologii, jak i w śpiewnikach masońskich początku XIX wieku wątków wskazujących na odwołania do transcendentnego porządku rzeczywistości spotykamy znacznie więcej. W zbiorach Elsnera i Gawdzickiego jest to motyw częsty, w zbiorach Wolańskiego bardzo częsty, a przegląd pieśni pozostałych w drukach ulotnych i odpisach sugeruje, że poza pieśniami związanymi $z$ samą realizacją rytu masońskiego podczas posiedzeń lożowych była to tematyka, jeśli nie dominująca, to w każdym razie podejmowana przy bardzo wielu okazjach.

Prawdopodobnie, w trakcie analizowania całości korpusu wierszy masońskich wrażenie może być nieco inne:

Gdzieś na marginesie tej twórczości pojawiły się wiersze filozoficzne mówiące o Bogu, o sensie życia ludzkiego czy celach związku mularskiego. Pojawiały się również wiersze patriotyczne, pisane pod wpływem nadziei rozbudzanych przez Napoleona, a za kilka lat przez Aleksandra I. [A 24]

Dla przykładu - w Pieśniku wolnomularskim Wolańskiego na 100 pieśni zebranych w tomie 9 to modlitwy lub hymny skierowane bezpośrednio do Boga, do tego można doliczyć pieśni śpiewane $z$ okazji świąt patronów lóż: św. Jana Ewangelisty i św. Jana Chrzciciela (A 20), a także kolejne wiersze zawierające wezwania do Stwórcy - Architekta świata. Były one formułowane w rocznicę założenia loży, pożegnania wyjeżdżających braci, uroczystości imienin, czyli święta patrona, śmierci członków zakonu, jak nazywano związek wolnych mularzy szczególnie tam, gdzie dochodziło do zetknięcia $z$ sytuacjami egzystencjalnymi: śmiercią, rozstaniem, powołaniem do ważnych funkcji i zadań, obudzeniem nadziei na lepsze jutro. Uniwersalizm ruchu odsuwał się na dalszy plan także wobec sytuacji zagrożenia i upadku ojczyzny, konieczności jej obrony, sięgnięcia po broń - lub radości ze 
względu na odzyskanie, na poczatku XIX wieku, nawet pozornych form suwerenności państwowej części dawnej Rzeczypospolitej. Zsakralizowana „miłość Ojczyzny” z towarzyszącym jej żądaniem ofiary z życia („nie żal żyć w nędzy, nie żal i umierać" - jak w ślad za Krasickim śpiewano w lożach) doskonale odpowiadała wolnomularskim nastrojom początku XIX stulecia, a także pierwszym latom stabilizacji po Kongresie Wiedeńskim. Brodziński pisał wówczas w wierszu skierowanym do Stanisława Kostki Potockiego i Aleksandra Rożnieckiego, a uznawanym za credo wolności masońskiej:

Jeślić przez długie wieki i rozliczne kraje
Oświecony ród ziemski cześć mularstwu daje
I Polak, co Ojczyznę odkupił przez blizny,
Zna i umie czcić dobro mularskiej ojczyzny,
Dzięki ci, światły Wodzu polskiego Zakonu!
Tobie, praca żyjący Namiestniku tronu!
Przy was polskie mularstwo, kwitnące wokoło,
Drogim żniwem prac waszych uwieńczy wam czoło ${ }^{26}$.

Spróbujmy uporządkować obserwacje związane z interesującym nas tematem już na podstawie konkretnych utworów literackich.

Autorzy pieśni wolnomularskich dotykających wątków religijnych operują zarówno frazeologia typową dla języka lożowego, dla różnorodnych nurtów refleksji o charakterze deistycznym, jak i dla ówczesnej poezji religijnej w ogóle. Ze znanych i oczywistych względów związanych $z$ historią wolnomularstwa najczęściej przywoływanym określeniem jest „Budownik”: Wielki Budownik (Gawdzicki), Budownik Światów (Wojciech Pękalski), Budownik natury, Budowniczy (Jakub Adamczewski), Wielki Architekt, Boska Istota, Istność, Przedwieczna Istność (w przekładzie z języka niemieckiego za F. Schillerem), Najwyższa Istność, Wieczna Istność, Twórca natury (Ludwik Adam Dmuszewski), Sprawca natury, Wielki Ojciec przyrodzenia (znów w ślad za Schillerem - w Pieśni o radości; w zbiorze Wolańskiego - Pochwała radości), Najwyższy (Gawdzicki), Władca świata (Brodziński) i podobne. W wierszu Wojciecha Bogusławskiego Pamięć dla ubogich adresatem początkowej apostrofy jest „Wieczna Istność”, określana potem terminem „Niebo”. W pieśni Ludwika Osińskiego z 1806 roku, rozpoczynającej się od incipitu „Co za Opatrzność nad nami”, będacej pochwała Napoleona, a po jego upadku i niewielkich zmianach frazeologicznych - cara Aleksandra I - Opatrzność jest przymiotem Stwórcy działającego w świecie. Obok tych sfomułowań pojawiają się określenia o charakterze metonimicznym - „Niebo” bądź „Niebiosa” (Bogusławski, Brodziński, Wężyk); czy synekdochicznym - „Opatrzność” (sprowadzenie Stwórcy do jednego z Jego przymiotów: Henryk Kałużyński, Wolański), tradycyjne wezwania do Stwórcy: „Panie” („Wesprzyj, o Panie, cnotliwych plemię" - w pieśni $O$ zgodzie braterskiej w zbiorze Wolańskiego, także u Brodzińskiego), „Panie [...], oświeć dzieci Twych mądrością” (Modlitwa, z niemieckiego, Wolański), „Panie nad Pany” (w zbiorze Gawdzickiego) albo po prostu „Bóg” - jak u Kniaźnina, Brodzińskiego lub w pięknej frazie: „Bóg zmierza czas toczącej się wieczności [...]”, w ostatniej pieśni zbioru Wolańskiego 
Duetto na zamknięcie loży (P 173; przekład z języka niemieckiego autora tej publikacji).

\author{
Cześć Twoja, o Władco świata, \\ Coś ulubił Zakon sobie, \\ Niech nas Twa wieczna oświata \\ Wiedzie drogą cnót ku Tobie! ${ }^{27}$
}

Zauważmy, że poza określeniami wywodzacymi się z tradycji wolnomularskiej sa to typowe zwroty charakterystyczne dla XVIII-wiecznej poezji nienacechowanej wyznaniowo, deistycznej $z$ ducha, lecz pisanej przez autorów odżegnujących się od deizmu lub zgoła osadzonej w tradycjach katolickich. Metonimia „Niebo” posługuje się np. Karpiński nie tylko w wierszu o tematyce społecznej Przeciwko Fanatyzmowi, wielokrotnie w Pieśniach nabożnych, ale nawet w utworach dotyczaçych zupełnie innej materii: w pieśni Przypomnienie dawnej miłości, w wierszu Starzec i córka. Myśl $z$ „Voyageur sentimental”, do U. D. S. W. Ten sam poeta odwołuje się do Opatrzności w odzie Do Wolności, w wierszach Przeciwko Deistom, Myśli jesienne. Do ksiażęcia Adama Czartoryskiego [...], a przede wszystkim w utworze O Opatrzności Boskiej z cyklu Pieśni nabożne. Podobnie czyni Krasicki, każąc Nipuańczykom oddawać cześć Najwyższej Istności, która kojarzy się nieodparcie $z$ terminologia deistyczną, lub wierzyć w Opatrzność ${ }^{28}$. Takich przykładów można wymienić znacznie więcej.

Wśród kontekstów biblijnych w pieśniach wolnych mularzy dominują wątki starotestamentowe. W zbiorze Gawdzickiego w Wierszu na uroczystość ś[więtego] Jana autor nawiązuje do początku Ksieggi Rodzaju (1, 1-5):

\footnotetext{
Jednym wyrzeczeniem słowa,

Z ciemności odwiecznej Nocy -

Dzieło Mądrości i Mocy -

Wzniosła się Świata budowa ${ }^{29}$.
}

Do tego samego fragmentu Genesis $(1,3)$ nawiązuje Brodziński w wierszu Potęga oświaty ${ }^{30}$. Ale przecież samo to odwołanie ma u źródła początek Ewangelii Janowej, które dopiero odsyła do Księgi Rodzaju, a obaj święci Janowie to postacie Nowego Testamentu. W tym samym zbiorze ludzi określa się zwrotem „Dzieci Adama”, jak w Mądrości Syracha (40, 1):

\footnotetext{
Wielka udręka stała się udziałem każdego człowieka i ciężkie jarzmo 〈spoczęło〉 na synach Adama, od dnia wyjścia $z$ łona matki, aż do dnia powrotu do matki wszystkich ${ }^{31}$.
}

K. B r o d zi ń s ki, Wiersz obrzędowy $w$ święto imienia N[ajprzewielebniejszego] i N[ajdoskonalszego] B[rata] Ludwika Osińskiego [...]. W: Poezje, t. 1, s. 30, 479. Szerzej na ten temat, wraz $z$ analizami frazeologicznymi i krótkim omówieniem literatury przedmiotu zob. J. T. Pokrzy wniak, Pisarz religijny. W: Ignacy Krasicki. Wśród pisarzy polskiego oświecenia. Poznań 2015, s. 131-132 n.

29 F. G aw d zi c ki, Wiersz na uroczystość ś[więtego] Jana. W: Pieśni wolnomularskie, s. [18], w. 3336.

30 K. Brodzińs ki, Potęga oświaty. W: Poezje, t. 2, s. 91, 469.

31 Biblia Jerozolimska. Wyd. 1. Poznań 2006, s. 987. 
Brodziński, w Wierszu na obchód żałobny po [...] Józefie Orsettim [...] z roku 1815, zwraca się do Jehowy ${ }^{32}$, wolni mularze odwołują się do tak ważnej dla nich tradycji budowniczych Świątyni Salomona (1 Krl 5-8), śpiewaja biesiadna Pieśń bankietowa ${ }^{33}$ na cześć Noego, który jako pierwszy zasadził winnicę i sporządził wino (Rdz 9, 20). Stosunkowo rzadko zdarzają się odniesienia do Nowego Testamentu, choć - jak widzieliśmy przy okazji przywoływania świętych patronów faktycznie są one częstsze, niż to się wydaje na pierwszy rzut oka. W praktyce lożowej, szczególnie tam, gdzie wolnomularze sięgali po symbolikę różokrzyżowców, nawiązań ewangelicznych było dużo przede wszystkim w przedstawieniach graficznych $^{34}$. Wojciech Pękalski - jedna $z$ ciekawszych postaci w gronie autorów pieśni wolnomularskich, zresztą zmarły wcześnie w niewyjaśnionych okolicznościach w zbiorze Elsnera, w Pieśni ogólnej (inc. „Bracia, w tym prawdy kościele”), przywołuje fragment z Ewangelii według św. Mateusza o dawaniu jałmużny (Mt 6, 1-4):

$$
\begin{aligned}
& \text { Spiesząc tam, gdzie rozpacz nęka, } \\
& \text { Gdzie biednym nędza doskwiera, } \\
& \text { Nie wie nasza lewa ręka } \\
& \text { O prawej, gdy łzy ociera. } \\
& \text { A ten, co pomoc znajduje, } \\
& \text { Nie nam, niech Niebu dziękuje }{ }^{35} \text {. }
\end{aligned}
$$

O ile niewielkie tomiki Elsnera, Gawdzickiego czy Budziszewskiego służą przede wszystkim najważniejszym praktykom lożowym, o tyle obszerny zbiór Wolańskiego jest dość niezwykły. Powstał stosunkowo późno, pod koniec drugiej dekady wieku XIX, w latach względnej stabilizacji pokongresowej, odczuwalnej także w środowisku masońskim. Niezwykłość zbioru polega głównie na tym, że w większym stopniu niż twórcy pozostałych śpiewników Wolański wykorzystuje dawne pieśni napisane przez wolnomularzy lub nawet inne XVIII-wieczne pieśni zaadaptowane na potrzeby lożowe. Zbiór ten datował autor jako kierowany do druku w październiku 5817 (1817) roku we wsi Wróble pod Inowrocławiem:

Niech Cię to nie urazi, łaskawy Br[acie] Czytelniku, że niektóre znajome Ci Pieśni przeformowane zostały. W części okoliczności tego wymagały, a w części będąc one przy szczególnym jakim zdarzeniu utworzone, potrzebowały przeistoczenia, aby się znowu przy podobnej okazyi przydały.

Upraszam Cię także, jeżeli Pieśni, jakie posiadasz, abyś mi one do drugiego Tomu tego Pieśnika łaskawie raczył udzielić, pod adresem:

Do W[ielmożne]go Wolańskiego, w Wróblach pod Inowrocławiem, w Ks[ięs]twie Poznańskim. [P [2]]

Mechanizm gromadzenia tekstów przez Wolańskiego wydaje się podobny do tego, z jakim wcześniej można było mieć do czynienia przy Elsnerowskiej praktyce kompozytorskiej (nie tylko wolnomularskiej). Otóż Elsner skomponował zbiór pieśni masońskich $z$ utworów sobie dostępnych, dopisując jedynie nowe melodie lub czerpiąc $z$ własnych już istniejacych. Ale dobierając utwory literackie do pieśni różnych od wykorzystywanych w praktyce lożowej, Elsner z reguły - poza pierwszą, 
wczesną fazą działalności kompozytorskiej - sięgał po teksty „światowe” (niemasońskie), których autorami również byli wolnomularze. Chętnie zatem komponował pieśni do słów Franciszka Dionizego Kniaźnina, Juliana Ursyna Niemcewicza, Ignacego Tańskiego, a potem także Jana Drozdowskiego, Ludwika Adama Dmuszewskiego, Ludwika Osińskiego, Brunona Kicińskiego i innych - współpracował też z Kazimierzem Brodzińskim. Poza nielicznymi wyjątkami (Niemcewicz, Kniaźnin) i utworami powstałymi jeszcze w latach osiemdziesiątych XVIII wieku autorzy ci na ogół pisali wiersze specjalnie na okazję śpiewu lożowego i nie zamieszczali ich już potem w swoich wydaniach zbiorowych, rozgraniczajac to, co przeznaczone dla uszu braci - i to, co dla profanów. Nie była to, oczywiście, reguła bezwyjątkowa (Kniaźnin, Niemcewicz, Tański), ale wystarczająco wyrazista, by można ją zaobserwować.

Otóż Wolański zbierał i układał w stosownej kolejności zarówno wiersze przeznaczone do praktyki lożowej (rytuału), jak i utwory inne, spełniające oczekiwania braci. Wykorzystywał w tym celu głównie wiersze znanych wolnomularzy: Adamczewskiego, Drozdowskiego, Kniaźnina etc. Zamieszczenie wierszy Kniaźnina stanowi pewną oczywistość, jako że należał on jeszcze w latach osiemdziesiątych wieku XVIII do loży „Świątynia Izis” wspólnie z wieloma współpracownikami Czartoryskich, a przede wszystkim wraz z samym Generałem Ziem Podolskich. Nie podając autora, przytacza więc Wolański cały wiersz Kniaźnina Hymn do Boga, rozpoczynający się od słów:

\author{
Od Ciebie moja niech zabrzmi lira \\ Twoją na zawsze strojona wiarą; \\ Znajoma Tobie moja myśl szczyra \\ I usta zgodne $z$ serca ofiara. \\ Czym tchnę, co czuję, co mię wzbić może, \\ Twoja to wola, Twoja moc, Boże! [P 95, w. 1-6]
}

Charakterystyczne, że Elsner nie sięgał po Kniaźninowe wiersze skierowane do Boga, zrobił to dopiero Wolański. Ale Wolański najwyraźniej szukał utworów właśnie o takiej tematyce.

Ten sam autor czy raczej redaktor zbioru wykorzystał kilka wierszy Krasickiego, znanych $z$ wydania Franciszka Ksawerego Dmochowskiego, a zatem w roku 1817, podczas przygotowywania Pieśnika wolnomularskiego, dostępnych na czytelniczym rynku. Poza pierwszym z cytowanych wierszy podaję partie początkowe lub charakterystyczne części tych utworów, przez Wolańskiego powtórzonych za Dmochowskim w całości. Tylko jeden $z$ wierszy został przytoczony przez autora zbioru we fragmentach.

Modlitwa należy do lepiej znanych wierszy Krasickiego ${ }^{36}$.

\footnotetext{
Stwórco! my Twoje stworzenia,

Chwałę Twoją święta głosim;
}

Zob. T. Kostkiewiczowa, Dodatek krytyczny. W: I. Krasicki, W: Dzieła zebrane. Pod red. Z. Golińskiego, kontynuowana przez J. T. Pokrzywniaka i M. Parkitnego. Seria pierwsza: Pisma literackie. T. 2: Zbiory wierszy. Oprac. T. Ko s tki e w i c zow a. Poznań 2019, s. 875-876. Dzieła zebrane. Seria 1. Red. Z. Goliń ski. Na fakt pojawienia się wierszy Krasickiego w tym zbiorze wskazywała już przed laty Wi ch row s ka (A 19). 


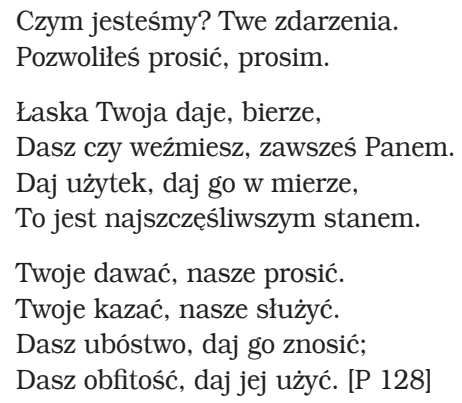

Krasickiego raczej nikt nigdy nie posądzał o związki z ruchem wolnomularskim. Sformułowania użyte przez XBW dobrze jednak oddają charakter oświeceniowych zwrotów do Stwórcy. Pod kolejnym numerem śpiewnika figuruje następny wiersz Krasickiego Ojczyźnie. Jak łatwo można się domyśleć, jest to Hymn (inc. „Święta miłości kochanej Ojczyzny”), dobrze znany od lat siedemdziesiątych XVIII wieku, jeden z najpopularniejszych i najdoskonalszych polskich wierszy oświeceniowych o tematyce patriotycznej. W czasie powstania listopadowego, a zatem w 13 lat później, stary już Elsner skomponował do niego nową melodię i Hymn Krasickiego w tej postaci służył powstańczym oddziałom. Ciekawe wszakże, czy Elsner kojarzył go wcześniej z lożowej praktyki, czy też po prostu wiersz Krasickiego był tak powszechnie znany?

Kolejna pieśń, zatytułowana Przyjaźni, stanowi trawestację wspomnianego Hymnu, dokonaną najpewniej przez Wolańskiego:

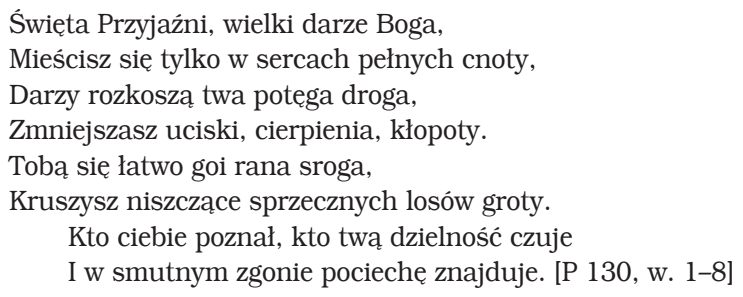

W dalszych częściach zbioru Wolańskiego znajdujemy jeszcze inne wiersze Krasickiego, m.in. utwór zatytułowany Niestateczność losu, znany z krytycznych wydań poety pod incipitem „Czemuż się skarżysz na Fortuny ciosy”. Wolański powtarza tytuł $z$ niewielkimi zmianami za Dmochowskim ${ }^{37}$ :

\footnotetext{
Czemu się skarżysz na Fortuny ciosy,

W twych użaleniach mniej baczny?

Nie wiesz, jakie są zmienne ludzkie losy,

Jaki jej humor dziwaczny? [P 42, w. 1-4]
}

Kolejnym utworem Krasickiego zamieszczonym przez Wolańskiego w zbiorze jest Hymn do Boga (u Dmochowskiego: Do Boga) ${ }^{38}$ :

K o s t k i e w i c z o w a, Dodatek krytyczny, s. 834-835. U Dmochowskiego tytuł brzmi: O niestateczności losu.

Ten sam wiersz Krasickiego parafrazował także I. Tański w dramatycznym wierszu Hymn do 
Do Ciebie, Panie, wznosim nasze prośby.

Czy cieszysz dary, czyli trwożysz groźby,

Zawsze jest szczęście pod Twym świętym progiem,

Boś Ty jest Bogiem.

Stwórco, stworzenie wsparcia Twego czeka,

Z niczegoś stworzył marnego człowieka,

A dając duszę, choć zejście przyśpieje,

Dałeś nadzieję.

[. . . . . . . . . . . . . . . . . . . .]

A w ten czas, czy człek płacze, czy się śmieje,

Ukrzepiającą zyskawszy nadzieje,

Oczy, co rzeźwi radość, smuci trwoga,

Wznosi do Boga. [P 50-51, w. 1-8, 17-20]

Charakterystyczne, że wśród odpisów znajdujących się w Ossolineum jedna z kopii zawiera strofe dopisana jako wersy 21-24 (strofa 6) przez innego autora, być może będąca świadectwem wolnomularskiej recepcji tekstu:

Wznosi, ponosząc przykrości i blizny,

Wznosi i czulej dla miłej Ojczyzny

I bardziej cierpiąc, kiedy ona traci,

Wznosi dla braci ${ }^{39}$.

Kolejny wiersz Krasickiego to Pociecha. Znamienne, że braci z „zakonu” pociągało to, co dla pisarstwa XBW najbardziej charakterystyczne, będące jednocześnie wyrazem jego postawy moralisty i mędrca czerpiącego natchnienie $z$ antycznych źródeł oświeceniowego klasycyzmu: wszechobejmująca zasada umiaru, złotego środka, spokojne znoszenie przeciwności losu, wewnętrzna niezależność, odrzucenie egoizmu, zaangażowanie w sprawy społeczne, wysiłek na rzecz odpowiedzialności społecznej, wreszcie troska o postawę głęboko moralną:

Gdy się los uprze czynić nieszczęśliwym,

Co czynić, widząc smutną alternatę?

Być trwałym w zdaniu, w przygodzie cierpliwym

I rzeczą zmienną zwać korzyść i stratę.

[. . . . . . . . . . . . ]

Myśleć: co innym, to też przyszło do mnie,

Myśleć: dla innych gorzej się rzecz wspaczy.

Przyjdzie los dobry, bierzmy dary skromnie,

Nie przyjdzie, podłej strzeżmy się rozpaczy. [P 57, w. 1-4, 9-12]

I jeszcze jeden wiersz XBW znalazł się w wolnomularskim zbiorze. Jest to Pieśn na dzień 3 maja roku 1792, z której pozostawiono pierwszą oraz trzecią strofę i opatrzono tak zmieniony utwór nowym tytułem - Modlitwa:

Wyższym nad nieba wzniosły majestatem,

Boże, co raczysz zawiadować światem

Boga za Rodziców (w: Wiersze i pisma różne. Dzieło pogrobowe. Warszawa 1808, s. 269). Rodzice Tańskiego zostali zamordowani przez Rosjan podczas rzezi Pragi w 1794 roku.

Cyt. za: Ko s t ki e wi c zow a, Dodatek krytyczny, s. 872. 
I dobrodziejstwy, czym jesteś, objawić, Pozwól się sławić!

Daj użyć, coś dał, w pokoju i zgodzie,

Daj ducha rady i męstwa w narodzie,

Podległość rządną, w swobodzie wstrzymałość, W działaniu trwałość! [P 169]

Zwróćmy uwagę, że w zbiorze Wolańskiego naliczyliśmy aż sześć utworów Księcia Biskupa Warmińskiego (pięć przytoczonych w całości, jeden we fragmentach) oraz jedna trawestacje jego wiersza.

W dwóch pierwszych dziesięcioleciach XIX wieku w środowiskach wolnomularskich daje się zaobserwować wyraźna potrzeba zwiększenia repertuaru poezji o odniesieniach religijnych. Pisano już w ślad za literatura przedmiotu, że brakowało tekstów pieśni i nut w ogóle, ale jak widać, braki te rysowały się w bardzo określonych obszarach tematycznych. Poza tym dość swobodnie adaptowano oświeceniową poezję religijną czy moralistyczną. Można więc sądzić, że albo zasada, której niezwykle rygorystycznie trzymał się Elsner, by teksty pieśni śpiewanych w loży wychodziły wyłącznie lub prawie wyłącznie spod pióra braci, w kilka lat później nie była już tak rygorystycznie przestrzegana, albo też Wolański, komponując zbiory ze znanych sobie bądź odnalezionych utworów w ówczesnych wydaniach, nie zwracał większej uwagi na lożową przynależność autorów lub po prostu o niej nie wiedział, a wiersze dobierał, dbając o stylistyczną i frazeologiczną odpowiedniość z masońskim „duchem”. Można również zaryzykować twierdzenie, że dla ruchu wolnomularskiego wraz z upływem lat XVIII-wieczna poezja oświeceniowa stanowiła po prostu stylistycznie, frazeologicznie, wyobraźniowo i wreszcie ideowo najbliższy wspólny obszar. Nie dotyczy to jednak wszystkich pisarzy, a tylko tych - jak właśnie Krasicki - w których twórczości rodzaj wyobraźni religijnej był najbliższy zracjonalizowanym formułom prezentującym podstawy porządku świata.

Inne wiersze pomieszczone w śpiewnikach, rozproszone w druczkach ulotnych, broszurach bądź rękopisach odzwierciedlają takie same lub podobne tendencje, których ślady obserwowaliśmy do tej pory:

Ty, co w opiece wszystkie masz ziemie,

Wesprzyj, o Panie, cnotliwych plemię.

(O zgodzie braterskiej, P 12, w. 17-18)

Nasz Budowniku, Tobie cześć i chwała,

Wielkość Twa w pośród tylu światów działa,

Moc wszelka pod Twą potęgą upada,

Twych niedościgła zamiarów zasada.

Natury skutkiem obfitej dowodzisz,

Jakeś łagodny, tak przeciwność słodzisz.

Wejrzyj na związek Mularzów cnotliwy,

Co głos z tej kuli wznosi do Cię tkliwy.

Dla zwycięstw cnoty, na ogromie świata,

Stawia Ci kościól, a zbrodnie umiata.

Zdrowym rozumem swe czyny kieruje

I trwałe szczęście dla wszystkich buduje.

(Hymn do Boga, P 75, w. 1-12) 
I jeszcze Hymn - tym razem pochodzący spoza zbiorów wymienionych na początku tego szkicu. Jest to niejako wiersz programowy, związany ze śmiercią jednego $\mathrm{z}$ braci, doskonale wpisujący się w założenia ruchu wolnomularskiego, wskazujący sytuację, kierunki działań, pożądane postawy...

Na próżno płochą nadzieją

Świat się za szczęściem upędza,

Idą z nim ciagłą koleją:

Cierpienie, smutek i nędza.

Wpośrzód nich człowiek się rodzi,

$Z$ nimi żyje na przemiany,

Żałując lub żałowany

Kresu swojego dochodzi.

Chór

Sama nawet doskonałość

Niedoli naszej obrazem;

Bo cóż jej pierwszym przykazem?

Cierpieć, a przytłumiać żałość.

Nie masz tego w naszym gronie,

Który był jego ozdobą,

A nam w tym świętym zakonie

Nie wolno płakać nad sobą.

Lecz kiedy jest cześć godniejsza

Nad łzy i jęki światowe,

Niech pamięć cnot żal umniejsza

I wróci straty połowę.

Chór

Bracia, uzbrojmy się w stałość,

Chociaż nas słuszny żal skłania,

Bo tak każe doskonałość:

Umieć cierpieć bez szemrania.

Zrzuciwszy znikome pęta,

Wolen podchlebstw i potwarzy,

Doszedłeś, gdzie prawda święta

Prowadzi wolnych mularzy.

Już wielki Budownik świata

Umieścił cię przed swym tronem,

Spraw, by cnót twoich oświata

Nie wygasła nad zakonem.

Chór

Bracia, uzbrojcie się w stałość,

Chociaż was słuszny żal skłania,

Bo tak każe doskonałość:

Umieć cierpieć bez szemrania ${ }^{40}$.

Czy można połączyć sygnalizowane tutaj cechy w jedno spójne rozpoznanie, pozwalające na wyodrębnienie tego rodzaju twórczości, którą trzeba by nazwać 
poezją religijną masonów polskich w dobie oświecenia, zwłaszcza późnego oświecenia? Wydaje się, że przedstawiony w niniejszym szkicu zarys wymaga jeszcze doprecyzowania i dalszych studiów szczegółowych, kilka cech tego pisarstwa można jednak wskazać.

Główny wyróżnik takiej poezji stanowi specyficzna frazeologia wolnomularska, która wyraźnie wyodrębnia wiersze masońskie z tych, które w punkcie wyjściowym nie były przeznaczone na użytek lożowy, powstawały na zewnątrz, poza środowiskiem wolnomularskim, i nie były przeznaczone do odśpiewania w lożach.

Wszakże środowisko masońskie, mimo pozorów zachowania tajemnicy i rytuału wzbudzającego lęk (lub ciekawość) profanów, nie funkcjonowało w społecznej i środowiskowej izolacji - ci sami poeci tłumaczyli niemieckie pieśni lożowe na język polski, pisali hymny, pieśni i modlitwy na wewnętrzny użytek braci oraz układali wiersze, nieraz o bardzo podobnej tematyce, drukowane „w świecie”, wśród profanów, czyli... w ich własnym środowisku literackim. Masońska frazeologia stanowiła jedynie znak rozpoznawczy, faktycznie zewnętrzny, identyfikacja ideowa miała nieporównywalnie głębszy charakter. Wolnomularska bezwyznaniowość była w dużej mierze pochodną ogólnooświeceniowego dezawuowania, a w dalszej konsekwencji negowania chrystocentrycznej specyfiki chrześcijaństwa. Nawet jeśli ten sposób rozumienia rzeczywistości nadprzyrodzonej nie wzbudził nad Wartą, Wisłą, Niemnem, Dźwiną i Dniestrem szerszego zainteresowania, to na pewno odcisnął się $\mathrm{w}$ językowych formułach dość powszechnie przyjętych w ówczesnej literaturze, omijających imię Zbawiciela i Najświętszej Marii Panny oraz wątki nowotestamentowe. Nie jest to wszakże odpowiedź na pytanie, czy - a jeśli tak, to jak głęboko zmieniła się wewnętrzna świadomość pisarzy posługujących się tą frazeologią. Stosunkowo późny przykład Brodzińskiego zdaje się wskazywać, że były to zmiany powierzchowne, znacznie wcześniejszy przykład Kniaźnina wymaga wnikliwszego naświetlenia, mimo iż istnieją już bardzo ważne i ciekawe propozycje interpretacyjne, nie uwzględniające jednak kontekstów masońskich lub uwzględniające je tylko w niewielkim stopniu ${ }^{41}$. W konsekwencji do zasobu utworów (zresztą o różnej wartości literackiej) śpiewanych w lożach weszły przede wszystkim pieśni typowe dla oświeceniowego myślenia o naturze transcendencji, a zwiększenie liczby wątków starotestamentowych było pochodna zarówno echa koncepcji masońskich, deistycznych, jak i oryginalnych niemieckich pieśni wywodzacych się z kręgu protestanckiego. Całość tych zjawisk nie wydaje się wszakże typowa dla polskiego oświecenia w ogóle, dość przypomnieć twórczość innych pisarzy lub inną część ich twórczości, by zobaczyć, że także pod tym względem jest to tylko jeden z nurtów pisania o transcendencji w Rzeczypospolitej w drugiej połowie XVIII wieku.

Podobna sytuacje obserwujemy $\mathrm{w}$ zespole wierszy piętnujących negatywne zjawiska społeczne i gloryfikujacych postawy humanitaryzmu. Jest to - jak sądze przede wszystkim wyraz krytycyzmu oświeceniowego właściwego epoce w ogóle, nie wymagającego powiązań $z$ tajnymi organizacjami. Jednak i tutaj właśnie frazeologia odróżniała poezję wolnomularską od wierszy profanów - potępienie fanatyzmu, ciemnoty, zabobonu, zbrodni przeciwko człowieczeństwu, oskarżenia pod adresem

41 Zob. T. Kos tki ew i c zow a, Transcendencja $w$ liryce Kniaźnina. W zb.: Motywy religijne $w$ twórczości pisarzy polskiego oświecenia. Red. ... Lublin 1995. 
wielkich instytucji dokonujących karygodnych nadużyć w przeszłości szło w parze z programem pozytywnym, będącym $z$ kolei przejawem oświeceniowego humanitaryzmu i dążenia do „oświecenia” szerokich warstw społecznych. Pochwała współczucia dla nieszczęścia, ubóstwa, działań na rzecz wsparcia nędzarzy i pokrzywdzonych - prowadziły do sakralizacji takich wskazanych już tu kategorii, jak Dobroczynność, Cnota, Przyjaźń, Oświata - a także Ojczyzna. Nie był to jednak program zasadniczo odrębny od idei propagowanych przez pisarzy polskiego oświecenia, choć stopień intensyfikacji w ich formułowaniu odbijał postulatywną utopijność wolnomularskiego programu. Wszakże podobnie jak w przypadku formuł odnoszacych się do sfery sacrum - odnotowujemy i na tym obszarze całą gamę zróżnicowanych postaw, które odzwierciedlają się w rozmaity sposób w twórczości poetyckiej.

\author{
Abstract \\ TOMASZ CHACHULSKI Cardinal Stefan Wyszyński University, Warsaw \\ ORCID: 0000-0001-7449-8022
}

\title{
POLISH MASON RELIOGIOUS POETRY A RECONNAISSANCE
}

Contrary to publishing a few crucial papers in the poetry of Polish Freemason poetry of the $18^{\text {th }} \mathrm{c}$. and beginning of $19^{\text {th }} \mathrm{c}$. (until circa 1831), the issue of Masonic religious verse has so far been discussed only marginally. It is uncertain whether, in general, we can use the term Masonic "religious" poetry, though it seems that, facing the continuously reappearing issues and a plethora of sacral motifs found in the pieces used in Freemasonic practice, we can resort to such category. The analysis is performed on a few collections of Masonic poetry from the beginning of the $19^{\text {th }}$ c., namely by Józef Elsner (1811), Feliks Gawdzicki (1814), Tadeusz Wolański (1817 and 1818), Franciszek Budziszewski (circa 1820) and other. The analysed threads and motifs indicate that the Masonic circle naturally applied characteristic phraseology, explicitly differentiating brethren from laymen, and a set of special Masonic songs connected with the rite; additionally they used the commonly known literary pieces that primarily reflected the attitudes to all forms of transcendence that were peculiar to the $18^{\text {th }} \mathrm{c}$. Enlightenment poetry. They eagerly resorted to Ignacy Krasicki's songs, and the Mason stylistics proved to have much in common with clusters or words as well as with formulas of poetry typical of both Classicism and Sentimentalism. Condemnation of fanatism, ignorance, and superstition, accusations of grand institutions for unpardonable overuse in the past went parallel to a positive programme, a symptom of the $18^{\text {th }} \mathrm{c}$. humanitarianism and strive to enlighten wide social groups, as well as led to sacralisation of such categories as Charity, Virtue, Friendship, Education, and also Homeland. 